TITLE:

\title{
Synergistic effect of fragrant herbs in Japanese scent sachets.
}

\author{
$\operatorname{AUTHOR}(\mathrm{S})$ :
}

Fujiwara, Yumi; Ito, Michiho

\section{CITATION:}

Fujiwara, Yumi ...[et al]. Synergistic effect of fragrant herbs in Japanese scent sachets.. Planta medica 2015, 81(3): 193-199

\section{ISSUE DATE:}

2015-02-11

URL:

http://hdl.handle.net/2433/198450

\section{RIGHT:}

(C) Georg Thieme Verlag KG Stuttgart· New York; 許諾条件により本文フ アイルは2016-02-11に公開.; This is not the published version. Please cite only the published version.; この論文は出版社版でありません。引 用の際には出版社版をご確認ご利用ください。 
The synergistic effect of fragrant herbs in Japanese scent sachets

Yumi Fujiwara ${ }^{1}$, Michiho Ito ${ }^{1}$

\begin{abstract}
Affiliation
${ }^{1}$ Department of Pharmacognosy, Graduate School of Pharmaceutical Science, Kyoto University
\end{abstract}

Correspondence

Yumi Fujiwara, Department of Pharmacognosy, Graduate School of Pharmaceutical Science, Kyoto University; 46-29 Yoshida-Shimo-Adachi-cho, Sakyo-ku, Kyoto 606-8501, Japan. E-mail: shoyaku.shigen@gmail.com. Phone: +81 757534506 


\section{Abstract}

The sedative activity of 8 aromatic natural medicines that are traditionally used in Japanese scent sachets was examined using an open field test with mice. Galangal (Kaempferia galanga), patchouli (Pogostemon cablin), sandalwood (Santalum album), spikenard (Nardostachys chinensis), cinnamon (Cinnamomum cassia), clove (Syzygium aromaticum), star anise (Illicium verum), and borneol (Dryobalanops aromatica) distilled oils were used. These natural medicines have various pharmacological effects. For example, galangal has insecticidal activity and clove extracts possess strong total antioxidant activity. Aromatherapy, a well-known complementary medicine system that uses inhalation, has recently attracted much attention. The sedative activity of inhaled aromatic compounds or essential oils has been examined by measuring the spontaneous motor activity of mice in an open field test. The galangal, patchouli, sandalwood, spikenard, and borneol oils showed significant sedative effects. The effect was stronger for a mixture of the 5 oils than for any of the single oils. This suggests that the oil mixture may have synergistic activity. Sedative activity was not observed when inactive oils (cinnamon, clove, and star anise) were added to the mixture of the 5 active oils.

\section{Keywords}

sedative effect, inhalation, fragrant herbs, synergestic effect

\section{Abbreviations}

AUC : area under the curve

FID : flame ionization detector

GABA : $\gamma$-aminobutyric acid

NREM : non-rapid eye movement

PAH : perillaldehyde

SEM : standard error of the mean

\section{Introduction}

In Japan it is a traditional custom to enjoy the fragrance of natural medicines using scent bags or sachets known as koubukuro. Aromatic natural medicines that emit fragrances at room temperature, such as galangal (Kaempferia galanga, Zingiberaceae), patchouli (Pogostemon cablin, Lamiaceae), sandalwood (Santalum album, Santalaceae), spikenard (Nardostachys chinensis, Santalaceae), cinnamon (Cinnamomum cassia, Laureaceae), clove (Syzygium aromaticum, Myrtaceae), star anise (Illicium verum, Illiciaceae), and borneol (Dryobalanops aromatica, Dipterocarpaceae), are commonly 
used for this purpose. The sachets can be carried in pockets and are also stored with clothes and paper as insect repellents. Similar scent sachets are used in Europe and China, although the fragrance materials vary.

These natural medicines have various pharmacological effects. For example, galangal has insecticidal activity [1] and clove extracts possess strong total antioxidant activity [2]. However, the majority of studies use extracts and there are very few that use essential oils. In animal experiments, the pharmacological effects of essential oils are usually administered orally, and by abdominal or percutaneous injection, rather than by inhalation. Aromatherapy, a well-known complementary medicine system that uses inhalation, has recently attracted much attention, and some interesting effects have been reported. Lavender essential oil shows antianxiety and antidepressant effects [3] and olfactory stimulation with black pepper oil significantly improves the sensory and reflexive motor movement of swallowing [4]. Further studies and trials for the clinical use of essential oils are needed to improve their effective use and increase the evidential background for therapies. The sedative activity of inhaled aromatic compounds or essential oils has been examined by measuring the spontaneous motor activity of mice in an open field test [5].

Sedative effects have been also been reported for some of the aromatic natural medicines found in Japanese scent sachets administered by inhalation. For example, the sedative activity of spikenard extract was examined using a spontaneous vapor administration system [6] and the main component of sandalwood, santalol, significantly decreased the total waking time and increased total non-rapid eye movement sleep time in rats [7]. In the present study, the chemical compositions of the distilled oil of natural medicines commonly used in Japanese sachets were analyzed, and their possible effects on spontaneous motor activity in mice were examined. Mixtures of oils were also investigated and we discuss the contribution of the results to the scientific background for traditional Japanese scent sachets.

\section{Results}

The analysis results for the 8 essential oils are shown in Tables 1S-8S, Supporting Information. The structures of the 2 main components of each essential oil are shown in Fig. 1S, Supporting Information. The yield of the essential oils for each natural medicine was calculated as $0.26 \%(\mathrm{w} / \mathrm{w})$ for galangal, $0.24 \%(\mathrm{w} / \mathrm{w})$ for patchouli, $0.20 \%(\mathrm{w} / \mathrm{w})$ for sandalwood, $0.23 \%(\mathrm{w} / \mathrm{w})$ for spikenard, $0.47 \%(\mathrm{w} / \mathrm{w})$ for cinnamon, $3.33 \%(\mathrm{w} / \mathrm{w})$ for clove, and $1.88 \%(\mathrm{w} / \mathrm{w})$ for star anise, per dry weight. The essential oils of galangal, sandalwood, clove, and star anise were colorless, and those of patchouli, 
spikenard, and cinnamon were pale yellow. Each oil had a characteristic odor.

Essential oils isolated by hydrodistillation were administered to mice by vapor inhalation, and their sedative activity examined. The doses of $4 \times 10^{-4}$ to $4 \times 10^{-2} \mathrm{mg}$ were calculated according to the range of doses that have been reported as effective for the same experimental system [8]. Perillaldehyde (PAH) is a major component in the essential oil of Perilla frutescens (Labiatae), and that was previously reported to have sedative and antidepressant-like effects on mice [9.10]. The results of administration of the essential oils are shown in Fig. 1. An activity of sedative effects of fragrant compound administered by inhalation often draws U-curve. This is in common with other sedative volatile compounds [6]. Sedative activity was observed for galangal, patchouli, sandalwood, spikenard, and borneol crystals. The strongest activities were observed at doses of $4 \times 10^{-4} \mathrm{mg}$ (galangal), $4 \times 10^{-3} \mathrm{mg}$ (patchouli), $4 \times 10^{-4} \mathrm{mg}$ (sandalwood), $4 \times 10^{-3} \mathrm{mg}$ (spikenard), and $4 \times 10^{-3} \mathrm{mg}$ (borneol crystals), respectively, and they were statistically significant (Fig. 1a-d and h, p < 0.05). During the first $10 \mathrm{~min}$ of administration, the locomotor activity of the mice decreased to approximately to two-thirds that of the control (Fig. 2). In contrast, none of the cinnamon, clove, and star anise oils showed sedative activity. Administration of these non-sedative oils caused a continuous increase of locomotor activity from 30 min onward, or abnormal behavior such as jumping, rapid movement, and frequent excretion. The control mice became calm and their locomotor activity was reduced to nearly zero after $30 \mathrm{~min}$.

There are a vast number of possibilities for generating combinations of 8 essential oils and doses. We initially investigated a sedative effect for a mixture of the 8 oils, although sedative activity was not observed at every concentration (data not shown). Therefore, mixtures of the 5 oils that showed a sedative effect were examined for synergistic effects. Furthermore, each of the inactive oils was added to the mixture of active oils and the sedative activity of these mixtures was also examined. The doses of the oil mixtures were the most effective doses for single administration. The composition of the mixtures of 5 active oils is shown in Table 1 . The results of the administration of oils are shown in Figures 3 and 4 . When the mixture of the 5 active oils was administered to mice, the locomotor activity decreased more than when the oils were administered individually. Although neither was significant, this result shows that the mixture of effective oils produced synergistic effects. When 3 inactive oils, namely, cinnamon, clove, and star anise, were added separately to the mixture of the 5 active oils, the activity of the mixtures was decreased.

Table 10S, Supporting Information shows the boiling point temperatures under atmospheric pressure, vapor pressure at $25^{\circ} \mathrm{C}$, and lipophilicity indicated by logP of the 
main components of each oil. Generally, the volatility of compounds increases as the boiling point decreases and the vapor pressure is higher. Higher lipophilicity increases the penetration rate through membranes and should increase the amount of compound absorbed. Three of the inactive oils have lower boiling points and higher vapor pressures compared with those of the 5 active oils. The activities of the oil mixtures containing an inactive oil were strongly affected by the main components of the inactive oils, probably because the inactive oils had high volatility and were thus dominant in the vapor. Some of the active oils have a lower vapor pressure; however, patchouli alcohol (patchouli), $\alpha$-santalol (sandalwood), and calarene (spikenard) have high lipophilicity and showed a fast effect because they are absorbed faster. These results suggest that the potency, volatility, and lipophilicity of the oil components may affect sedative activity.

\section{Discussion}

The sedative effect of galangal hexane extract administered by inhalation has been examined. Huang [11] reported that inhaling the hexane extract at a dose of 1.5 and 10 mg produced a significant reduction in locomotor activity. The 2 main aromatic compounds, ethyl $p$-methoxycinnamate and ethyl cinnamate, showed sedative effects at doses of 0.0014 and $0.0012 \mathrm{mg}$, respectively [11]. In the present report, the distilled galangal oil showed sedative activity at a dose of $4 \times 10^{-4}$. The distilled oil produced a sedative effect at a lower dose that the hexane extract. Organic solvents extract both the volatile and the nonvolatile compounds, whereas the distilled oil only contains the volatile compounds. For inhalation, where the volatile compounds are most important, the distilled oil is more effective than the hexane extract, and this produced a difference in effective dose. The distilled oil produced sedative activity at one-third of the dose of a single compound, suggesting that sedative activity observed in this report was caused by the whole oil.

The most abundant component in patchouli was patchouli alcohol (66.2\%). Patchouli alcohol has been reported to be responsible for the sedative activity of Microtoena patchouli essential oil. The effective dose of patchouli alcohol is 75-750 $\mu \mathrm{g}$ [12]. This dose is about 25-fold greater than the effective dose of patchouli oil in this report, which was $4 \times 10^{-3} \mathrm{mg}$. As was the case with galangal, patchouli essential oil has a higher sedative activity compared with its individual components.

The most abundant compounds in sandalwood- $\alpha$-santalol and trans- $\beta$-santalol — contribute to the characteristic odor of sandalwood oil and have many pharmacological effects $[13,14]$. Santalol caused a significant increase in total non-rapid eye movement (NREM) sleep time [7], suggesting that santalol has sedative activity. 
Twenty-six components were identified in spikenard essential oil, and most of them were sesquiterpene compounds. Cedarwood or sandalwood oils, which have high sesquiterpene contents, are often used for inhalation to produce relaxing effects. Calarene, $\alpha$-gurjunene [6] and $\beta$-maaliene [8] have sedative activities at doses of $0.17 \%$, $1.5 \%$, and $0.014-0.14 \%$, respectively. In contrast, the active dose observed in this paper was $4 \times 10^{-3} \mathrm{mg}$. These results indicate that the sedative activity is caused by multiple sesquiterpene components rather than a single compound.

Fifteen compounds were identified in clove essential oil. It has been reported that eugenol may improve learning and memory, although the dose dependency was not investigated [15]. Tianpeng et al. reported that inhaling eugenol changed the amount of neurotransmitters in the hippocampus and cortex. Levels of glutamate and choline acetyltransferase, an excitatory neurotransmitter, were significantly increased, whereas that of $\gamma$-aminobutyric acid (GABA), an inhibitory neurotransmitter, was not. These results may indicate that elevating the levels of excitatory neurotransmitters was caused by inhaling eugenol. The excitatory motion of the mice in this study, such as rapid movement and jumping, was consistent with these results. Inhaling eugenol appeared to produce a central nervous stimulatory effect.

Aromatic natural medicines have characteristic scents. The most abundant components may contribute heavily to the scent; however, the sedative effects of the essential oils do not appear to arise from single compounds, because oils consist of small amounts of various different compounds. The pharmacological effects observed in this study could not be related to the individual main components of the essential oils, suggesting that sedative effect arose from the whole oil.

The mixture of the 5 active oils decreased the locomotor activity of the mice more than did the individual oils. This showed that the mixture of active oils produces synergistic effects. The decrease in locomotor activity was small compared with the increase in the number of components, and it did not reach 2-fold that for the individual oils. This applied to mixtures of active oils that did not contain a large amount of a single component or components with an excitatory effect. Patchouli alcohol, borneol, and isoborneol constituted more than $50 \%$ because they are lower effective compounds and bigger amount were required for their highest activity. However, combination of the species of compounds in the mixture oil is different from what it was in each oil, and it might be dangerous to conclude the activity be attributed to those large-amount constituents. However, it is certain that the mixture of active oils produces synergistic effects.

A possible biological mechanism behind the pharmacological activity may involve the 
cerebral limbic system [16]. When a volatile component molecule reaches the nose, it binds to an olfactory receptor on an olfactory cell. The fragrance information is transmitted to the cerebral limbic system, and then to the hypothalamus, where it affects the autonomic nervous system and the endocrine system. Serizawa et al. reported that mice have more than 1000 olfactory receptor genes, and each olfactory cell expresses a single olfactory receptor gene for a receptor that detects a volatile component molecule with a specific structure. The axons of each olfactory cell in an olfactory bulb extend to one of 2000 glomeruli and form a neural circuit; thus, each glomerulus corresponds to 1 olfactory receptor [17]. Assuming that the sedative effect observed in this study only arises from this pathway, the results for the mixture of the 5 active oils can be explained as follows. The mixture of the 5 active oils showed a synergistic effect, although the spontaneous activity did not decrease in proportion to the increase in the number of compounds. If the proposed mechanism is accurate, when many volatile component molecules compete to bind to a limited number of olfactory receptors, not all the molecules will bind, and consequently the sedative activity should correspond to the number of receptors.

When the inactive cinnamon, clove, and star anise oils were added individually to the mixture of the 5 active oils, there was a significant decrease in sedative activity. Interestingly, none of the resultant mixtures exhibited sedative activity, despite the small ratio of the inactive oil to the active oil mixture of 1:5. The most abundant components of the cinnamon, clove, and star anise inactive oils are cinnamaldehyde, eugenol, and anethole, respectively. Iwasaki et al. reported that an intravenous injection of cinnamaldehyde increased adrenaline secretion in rats. The secretion of adrenaline occurs through the activation of the transient receptor potential ankyrin1 ion channel, which is involved with transmission of pain, by volatile irritants, such as allyl isothiocyanate or cinnamaldehyde [18]. The administration of GABA elicited a bimodal response in locomotion that was not dose-dependent; a lower dose elicited a small increase in locomotion, whereas a higher dose elicited a reduction. In addition, GABA attenuated locomotion, although it did not abolish locomotion in dopamine-stimulated locomotor activity [19]. Therefore, our results suggest that the 3 main compounds of the inactive oil produced adrenaline secretion and show an excitatory activity, whereas the inhibitory activity was mediated by GABA. The effect is not dose-dependent and does not completely suppress excitatory activity, meaning that it shows an overall excitatory effect.

We investigated the sedative effect of inhaling vapors from 8 aromatic natural medicines using the decrease in spontaneous motor activity of mice as a model for 
relaxation. We also examined the effect of mixtures of the 5 active essential oils, and observed a synergistic effect. Our results suggest that fragrance materials that have experiential benefits may also have a pharmacological sedative effect. This evidence can be used as the basis for possible medical applications and product development. Inhalation is a simple, noninvasive administration method, and the use of several natural products with low activities should reduce the likelihood of adverse side effects. Therefore, the inhalation of essential oils is a promising alternative method for treating and preventing a wider range of diseases. We expect that future studies of the sedative effects of essential oils mixtures will provide further useful results.

\section{Materials and Methods}

\section{Materials}

Eight fragrant herbs, galangal (K. galanga), patchouli (P. cablin), sandalwood (Sa. album), spikenard ( $N$. chinensis), cinnamon (C. cassia), clove (Sy. aromaticum), star anise (I. verum), and borneol (D. aromatica), were purchased from Mitsuboshi Pharmaceutical Co., Ltd., Nara, Japan. The batch numbers of there purchased products are as follows: 567A (K. galanga), 591A (P. cablin), 2687D (Sa. album), 591C ( $N$. chinensis), 7015(C. cassia), 517A (Sy. aromaticum), 585B (I. verum), 09144206 (D. aromatica). Voucher specimens of 8 fragrant herbs were deposited in the herbarium of Experimental Station for Medicinal Plants, Graduate School of Pharmaceutical Sciences, Kyoto University (Specimen numbers: EST-5009 (K. galanga), EST-5010 (P. cablin), EST-5012 (Sa. album), EST-5011 (N. chinensis), EST-5013 (C. cassia), EST-5014 (Sy. aromaticum), EST-5015 (I. verum), EST-5016 (D. aromatica)). Triethyl citrate (Merck KGaA, Darmstadt, Germany), an odorless solvent, was used to dissolve the fragrance components. DL-perillaldehyde (Tokyo Kasei Co., Ltd., Tokyo, Japan.) was used as positive control. The authentic compounds decane, dodecane, tetradecane, hexadecane, octadecane (Wako Pure Chemical Industries Co., Ltd., Osaka, Japan.), docosane, tetracosane (Nacalai Tesque Co., Ltd., Kyoto, Japan.), eicosane, pentacosane, hexacosane (Tokyo Kasei Co., Ltd., Tokyo, Japan.), were prepared as the gas chromatography retention indices. All other chemicals and reagents used in this study were of the highest grade available.

\section{Distillation of aromatic natural medicines}

The aromatic natural medicines (100 g, each), except for borneol, were hydrodistilled for $2 \mathrm{~h}$ using the clevenger-type apparatus designated in the Japanese Pharmacopoeia 16th edition and the distilled oil was captured in hexane. The essential oil was dried 
over anhydrous sodium sulfate and stored at $-20{ }^{\circ} \mathrm{C}$ before analysis and animal experiments.

\section{GC and GC/MS analysis}

Qualitative analysis of the volatile components was performed by GC/MS (6850GC/5975MSD, Agilent Technologies) under the following operating conditions. Fused silica capillary column, DB-Wax (Agilent Technologies), $60 \mathrm{~m} \times 0.25 \mathrm{~mm}$, film thickness of $0.25 \mu \mathrm{m}$; column temperature program for galangal: $60-240{ }^{\circ} \mathrm{C}$ increasing at $3{ }^{\circ} \mathrm{C} / \mathrm{min}$, holding at $240{ }^{\circ} \mathrm{C}$ for $30 \mathrm{~min}$; column temperature program for other materials: $60-210{ }^{\circ} \mathrm{C}$ increasing at $3{ }^{\circ} \mathrm{C} / \mathrm{min}$, holding at $210{ }^{\circ} \mathrm{C}$ for $30 \mathrm{~min}$; injector, $100{ }^{\circ} \mathrm{C}$; carrier gas, helium, $26 \mathrm{~cm} / \mathrm{min}$; split ratio, 100:1; injection volume, $1 \mu \mathrm{L}$; ionization energy, $70 \mathrm{eV}$.

Quantitative analysis of volatile components was performed by GC (G5000, Hitachi) with a flame ionization detector (FID) under the following operating conditions. Fused silica capillary column, InertCap-Wax (GL Sciences), $60 \mathrm{~m} \times 0.25 \mathrm{~mm}$, film thickness = $0.25 \mu \mathrm{m}$; column temperature program, same as for $\mathrm{GC} / \mathrm{MS}$; injector, $100{ }^{\circ} \mathrm{C}$; detector for galangal, $250{ }^{\circ} \mathrm{C}$; detector for other materials, $220{ }^{\circ} \mathrm{C}$; carrier gas, helium, 0.8 $\mathrm{cm} / \mathrm{min}$; split ratio, 100:1; injection volume, $1 \mu \mathrm{L}$.

The retention indices of the components were calculated on the InertCap-Wax column using $n$-alkane standards. The compounds were identified by comparing the fragmentation pattern of the mass spectra with those available from the National Institute of Standards and Technology and flavors libraries. Quantitative analysis was achieved with an FID.

\section{Animals}

Animal experiments were designed following the recommendations of the Animal Research Committee of Kyoto University, Kyoto, Japan (the approval number was 2012-18). Experimental procedures involving the use and care of animals conformed to the institutional guidelines, which comply with the Fundamental Guidelines for the Proper Conduct of Animal Experiments and Related Activities in Academic Research Institutions under the jurisdiction of the Ministry of Education, Culture, Sports, Science, and Technology, Japan (2006).

Male 4-week-old ddY mice were purchased from Japan SLC (Shizuoka, Japan). The mice were housed in colony cages at an ambient temperature of $25 \pm 2{ }^{\circ} \mathrm{C}$ and relative humidity of $50 \pm 10 \%$ with a 12 h light-dark cycle before being used for experiments. They were fed standard pellet chow and water ad libitum. All behavioral observations 
were conducted between 10:00 and 17:00 at the same temperature and humidity.

\section{Evaluation of spontaneous motor activity}

The sedative activities of the fragrant components were evaluated in mice by their spontaneous motor activity in an open field test described in a previous report [6]. The distilled oils and borneol crystals were dissolved in triethyl citrate (400 $\mu \mathrm{L}$ total), at concentrations ranging from $4 \times 10^{-4}$ to $4 \times 10^{-2} \mathrm{mg}(\mathrm{v} / \mathrm{v})$ in a glass cage (W $60 \times \mathrm{L} 30 \times$ $\mathrm{H} 34 \mathrm{~cm}$ ). The samples were dropped onto 4 filter paper disks (100 $\mu \mathrm{L}$ each), which were placed on the wall of the glass cage using adhesive tape. The solution vapor was allowed to fill the cage by natural diffusion for $60 \mathrm{~min}$. A mouse was placed in the center of the cage and was monitored by a video camera for another $60 \mathrm{~min}$. The frequency at which the mouse crossed lines drawn on the bottom of the cage at $10 \mathrm{~cm}$ intervals was counted every $5 \mathrm{~min}$ for $60 \mathrm{~min}$. The area under the curve (AUC), indicating total locomotor activity over $60 \mathrm{~min}$, was calculated by the trapezoidal rule [20]. All values are expressed as the mean \pm the standard error of the mean (SEM). Statistical analyses were carried out using Dunnett's test using GraphPad Instat3 (GraphPad Software, San Diego, CA). A probability level of $P<0.05$ was taken to be statistically significant in the analysis. The results were reproducible; therefore, 5 mice from each administration group were chosen at random for statistical analysis.

\section{Conflict of interest}

The authors declare no conflict of interest.

\section{References}

1 C. Pandji, C. Grimm, V. Wray, L. Witte, P. Proksch. Insecticidal constituents from four species of the Zingiberaceae. Phytochemistry 1993; 34: 415-419.

2 I. Gulcin, I. G. Sat, S. Beydemir, M. Elmastas, O. I. Kufrevioglu. Comparison of antioxidant activity of clove (Eugenia caryophylata Thunb) buds and lavender (Lavandula stoechas L.). Food Chem 2004; 87: 393-400.

3 H. M. A. Cavanagh, J. M. Wilkinson. Biological activities of lavender essential oil. Phytother Res 2002; 16: 301-308.

4 T. Ebihara, S. Ebihara, M. Maruyama, M. Kobayashi, A. Itou, H. Arai, H. Sasaki. A randomized trial of olfactory stimulation using black pepper oil in older people with swallowing dysfunction. J Am Geriatr Soc 2006; 54: 1401-1406.

5 G. Buchbauer, L. Jirovetz, W. Jager, C. Plank, H. Dietrich. Fragrance compounds and essential oils with sedative effects upon inhalation. J Pharm Sci 1993; 82: 
660-664.

6 H. Takemoto, M. Ito, T. Shiraki, T. Yagura, G. Honda. Sedative effects of vapor inhalation of agarwood oil and spikenard extract and identification of their active components. J Nat Med 2008; 62: 41-46.

7 A. Ohmori, K.Shinomiya, Y. Utsu, S. Tokunaga, Y, Hasegawa, C. Kamei. Effect of santalol on the sleep-wake cycle in sleep-disturbed rats. Nihon Shinkei Seishin Yakurigaku Zasshi 2007; 27: 167-171.

8 H. Takemoto, T. Yagura, M. Ito. Evaluation of volatile components from spikenard: valerena-4,7(11)-diene is a highly active sedative compound. J Nat Med 2009; 63: 380-385.

9 G.Honda, Y.Koezuka, W.Kamisako, M.Tabata. Isolation of sedative principles from Perilla frutescens. Chem Pharm Bull 1986; 34: 1672-1677.

10 N.Ito, T.Nagai, T.Oikawa, H.Yamada, T.Hanawa. Antidepressant-like effect of $l$-perillaldehyde in stress-induced depression-like model mice through regulation of the olfactory nervous system. Evid Based Complement Alternat Med 2011; 512697.

11 L. Huang, T. Yagura, S. Chen. J. Sedative activity of hexane extract of Keampferia galanga L. and its active compounds. Ethnopharmacol 2008; 120: 123-125.

12 K. Ito, M. Ito. Sedative effects of vapor inhalation of the essential oil of Microtoena patchoulii and its related compounds. J Nat Med 2011; 65: 336-343.

13 B. B. Misra, S. Dey. Evaluation of in vivo anti-hyperglycemic and antioxidant potentials of $\alpha$-santalol and sandalwood oil. Phytomedicine 2013; 20: 409-416.

14 B. B. Misra, S. Dey. Biological activities of East Indian sandalwood tree, Santalum album. PeerJ PrePrints 2013; e96v1.

15 Y. Tianpeng, T.Min, L. Qiaoqiong, L. Guangwu. Mechanisms of eugenol improving learning and memory through olfactory pathway on Kunming mice. Zhongguo Kangfu Yixue Zazhi. 2007; 22: 487-489.

16 D. Kagawa, H. Jokura, R. Ochiai, I. Tokimitsu, H. Tsubone. The sedative effects and mechanism of action of cedrol inhalation with behavioral pharmacological evaluation. Planta Med 2003; 69: 637-641.

17 S.Serizawa, K.Miyamichi, H.Nakatani, M.Suzuki, M.Saito, Y.Yoshihara, H.Sakano. Negative feedback regulation ensures the one receptor-one olfactory neuron rule in mouse. Science 2003; 302: 2088-2094.

18 Y. Iwasaki, M. Tanabe, K. Kobata, T. Watanabe. Biosci. TRPA1 agonists-allyl isothiocyanate and cinnamaldehyde-induce adrenaline secretion. Biotechnol Biochem 2008; 72: 2608-2614.

19 D. L. Jones, G. J. Mogenson, M. Wu. Injections of dopaminergic, cholinergic, 
serotoninergic and gabaergic drugs into the nucleus accumbens: effects on locomotor activity in the rat. Neuropharmacology 1981; 20: 29-37.

20 Burden, Richard L, J. Douglas Faires. Numerical Analysis, 9th edition; 2010: 193-202.

21 The Good Scent Company. http://www.thegoodscentscompany.com/ Accessed July 10, 2013.

\section{Legends for Figures}

Fig. 1 Total spontaneous motor activity of mice given (a) galagal, (b) patchouli, (c) sandalwood, (d) spikenard, (e) cinnamon, (f) clove, (g) star anise essential oils, and (h) borneol crystals. Data are shown as means \pm SEM for 5 mice. Statistical differences vs. the control group were calculated using analysis of variance, followed by Dunnett's test. ${ }^{*} p<0.05$ and ${ }^{* *} p<0.01$.

Fig. 2 Locomotor activity transition of mice given essential oils.

Fig. 3 Comparison of the effect of essential oils on locomotor activity of mice treated with galangal (4 × $\left.10^{-4} \mathrm{mg}\right)$, patchouli $\left(4 \times 10^{-3} \mathrm{mg}\right)$, sandalwood $\left(4 \times 10^{-4} \mathrm{mg}\right)$, spikenard $\left(4 \times 10^{-3} \mathrm{mg}\right)$, crystal of borneol $\left(4 \times 10^{-3} \mathrm{mg}\right)$ and a mixture of the 5 active oils. Data are shown as means \pm SEM for 5 mice. Statistical differences vs. the mixture of the 5 active oils were calculated using Student's $t$-test. Neither was significant.

Fig. 4 Comparison of the effect of essential oils on locomotor activity of mice treated with 3 inactive oils, a mixture of the 5 active oils and the mixtures of oils composed of the 5 active oils with either of the 3 inactive oils. The doses of 3 inactive oils were cinnamon ( $\left.4 \times 10^{-3} \mathrm{mg}\right)$, clove $\left(4 \times 10^{-4} \mathrm{mg}\right)$, star anise $\left(4 \times 10^{-3} \mathrm{mg}\right)$. Data are shown as means \pm SEM for 5 mice. Statistical differences vs. the mixture of the 5 active oils were calculated using Student's $t$-test. ${ }^{*} p<0.05$ and ${ }^{* *} p<0.01$. 
Table

Table 1. Composition of a mixture of the 5 active oils

\begin{tabular}{|c|c|c|}
\hline Compound $^{\mathrm{a}}$ & $\mathrm{RI}^{\mathrm{b}}$ & Peak Area(\%) ${ }^{\mathrm{C}}$ \\
\hline$\beta$-patchoulene & 1681 & 0.4 \\
\hline$\alpha$-copaene & 1688 & 0.3 \\
\hline aristolene & 1784 & 0.7 \\
\hline calarene & 1811 & 4.2 \\
\hline$\alpha$-gurjunene & 1839 & 1.2 \\
\hline seychellene & 1865 & 2.0 \\
\hline calaradiene & 1882 & 0.8 \\
\hline isoborneol & 1885 & 6.8 \\
\hline borneol & 1916 & 23.4 \\
\hline$\alpha$-bulnesene & 1929 & 0.3 \\
\hline anethole & 2024 & 0.5 \\
\hline$\beta$-ionone & 2100 & 1.1 \\
\hline caryophyllene oxide & 2133 & 0.8 \\
\hline (-)-globulol & 2181 & 0.6 \\
\hline spathulenol & 2206 & 1.9 \\
\hline ethyl cinnamate & 2213 & 0.8 \\
\hline patchouli alcohol & 2242 & 18.8 \\
\hline$\alpha$-santalol & 2309 & 1.9 \\
\hline$\beta$-santalol & 2343 & 2.3 \\
\hline ethyl $p$-methoxycinnamate & 2431 & 2.5 \\
\hline Total identified & & 71.1 \\
\hline unknown & & 28.9 \\
\hline
\end{tabular}

${ }^{\mathrm{a}}$ Order of elution is on an InertCap-Wax column.

${ }^{\mathrm{b}} \mathrm{RI}$ is the retention index, calculated against C10-C26 n-alkanes on an InertCap-Wax column.

${ }^{\mathrm{C}}$ Peak area percentage is determined by calculating the peak area of the FID chromatogram. 
Fig. 1
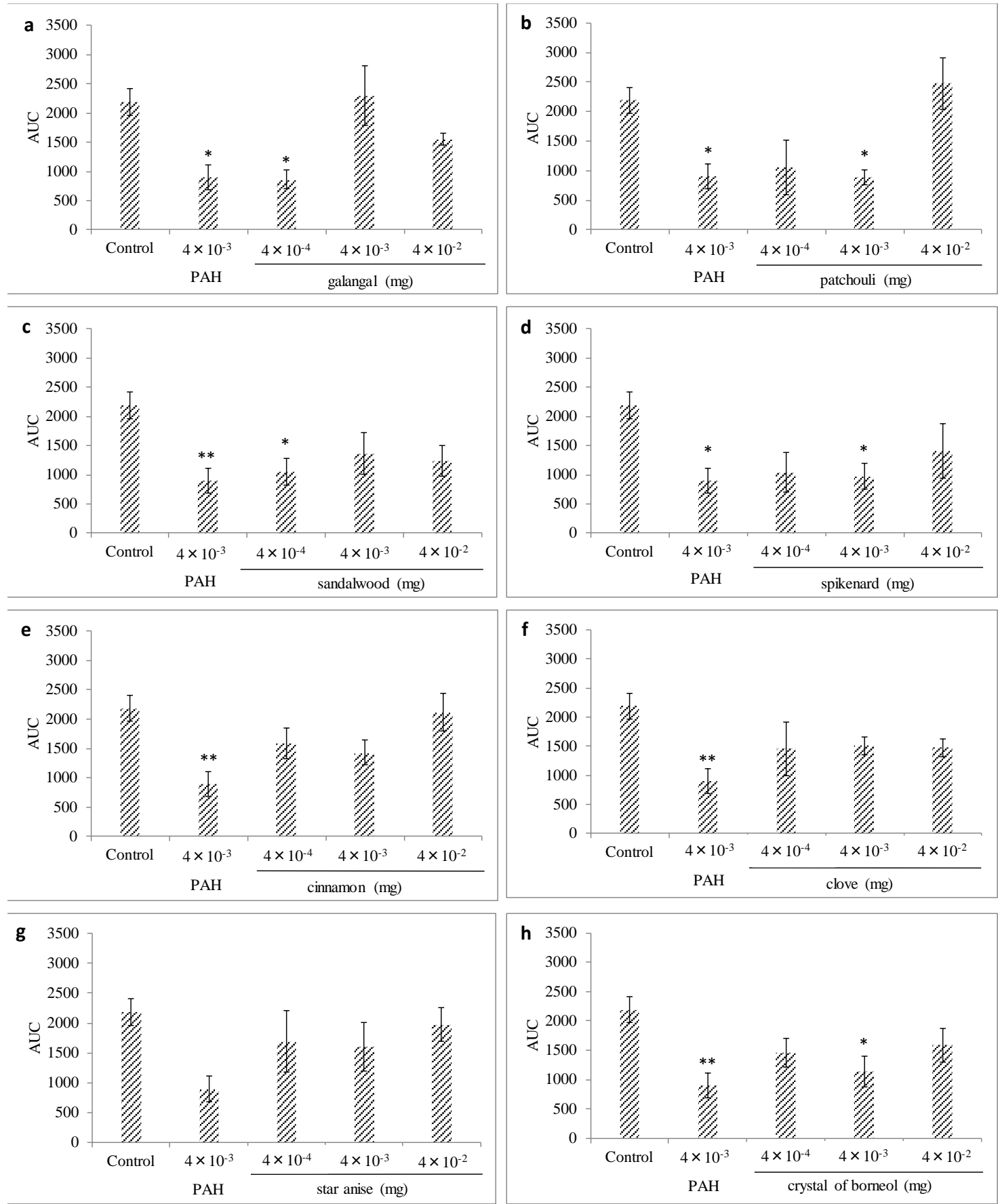
Fig. 2

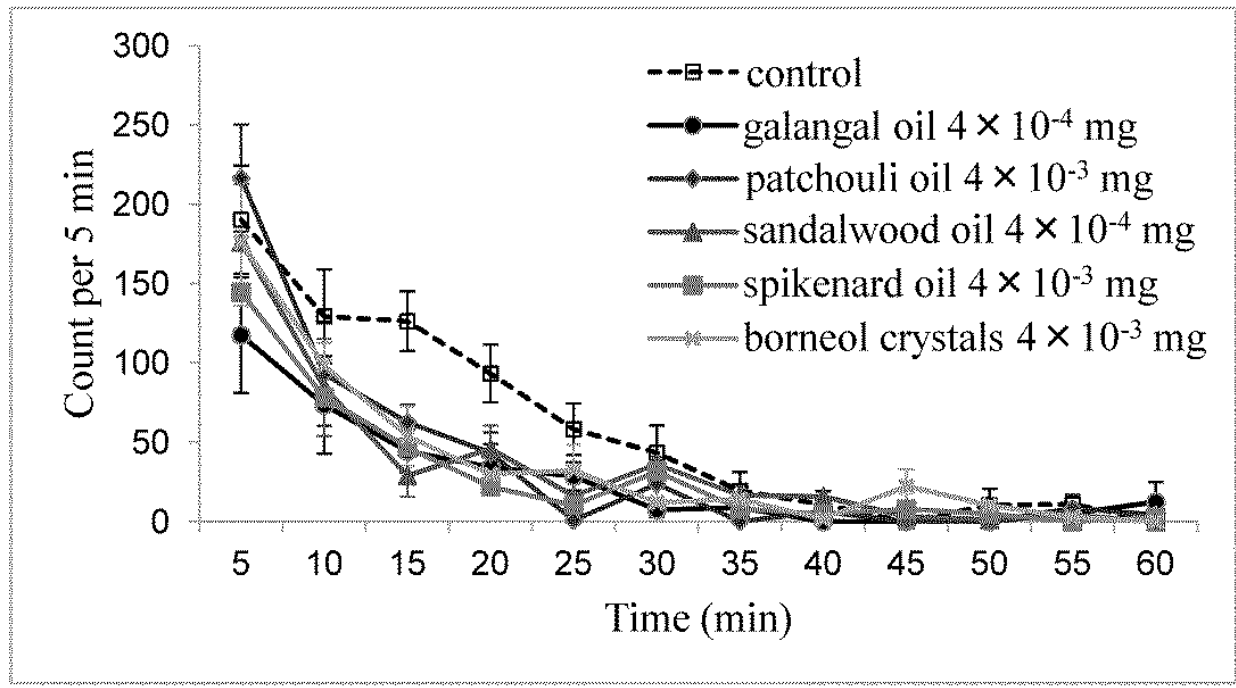


Fig. 3

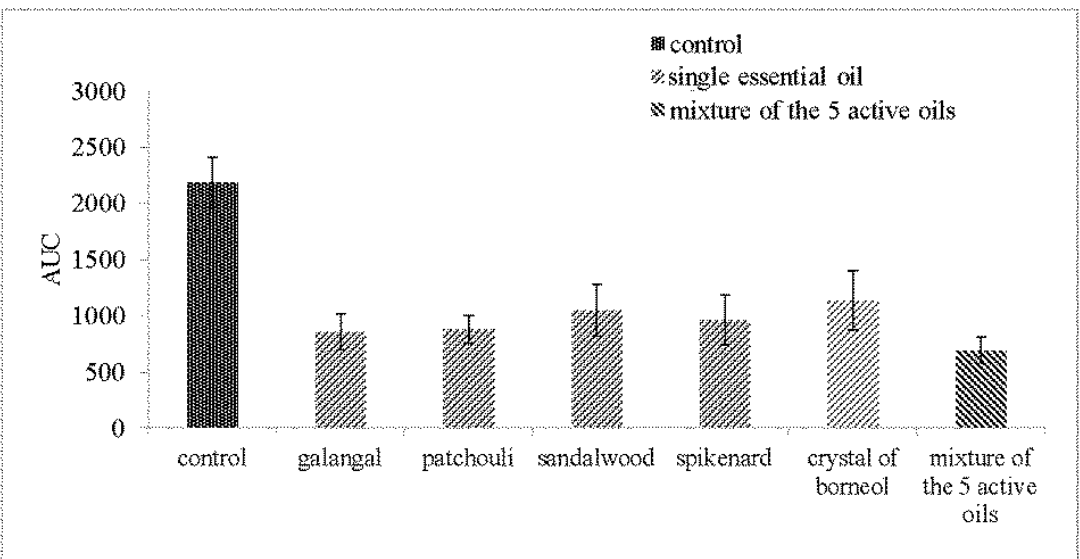


Fig. 4

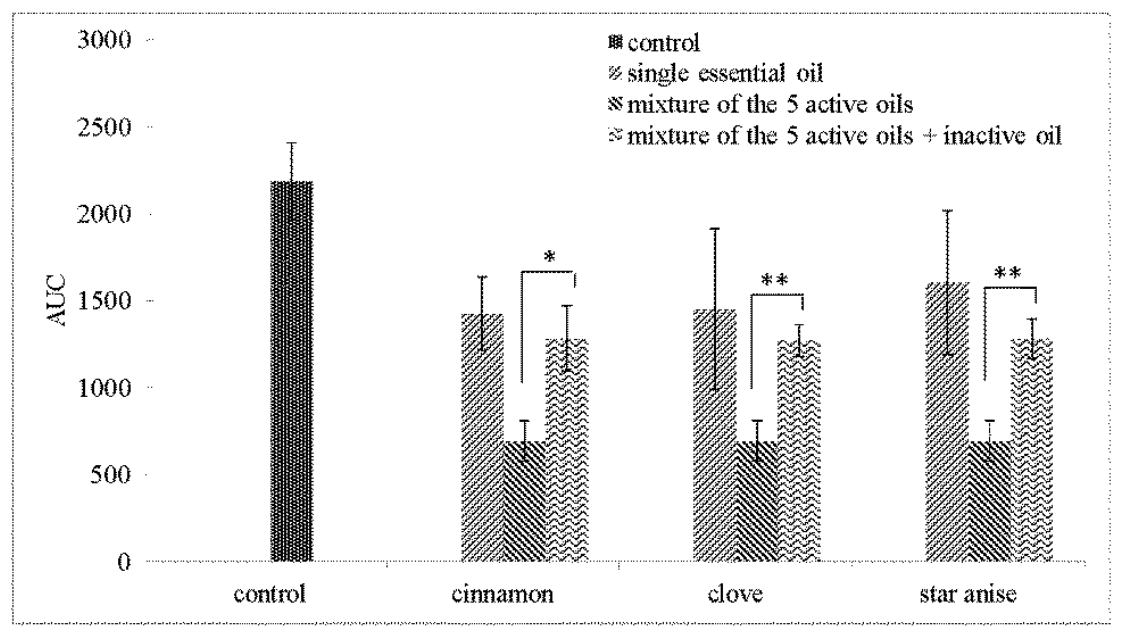


Supporting Information

The synergistic effect of fragrant herbs in Japanese scent sachets

Yumi Fujiwara ${ }^{1}$, Michiho Ito ${ }^{1}$

\section{Affiliation}

${ }^{1}$ Department of Pharmacognosy, Graduate School of Pharmaceutical Science, Kyoto University

\section{Correspondence}

Yumi Fujiwara, Department of Pharmacognosy, Graduate School of Pharmaceutical Science, Kyoto University; 46-29 Yoshida-Shimo-Adachi-cho, Sakyo-ku, Kyoto 606-8501, Japan. E-mail: shoyaku.shigen@gmail.com. Phone: +81 757534506

\section{Legends for Figure}

Fig. 1S Structures of the main components of essential oils of (a) galangal, (b) patchouli, (c) sandalwood, (d) spikenard, (e) cinnamon, (f) clove, (g) star anise, and (h) borneol crystals.

\section{Legends for Tables}

Table 1S. Composition of galangal oil

Table 2S. Composition of patchouli oil

Table 3S. Composition of sandalwood oil

Table 4S. Composition of spikenard oil

Table 5S. Composition of cinnamon oil

Table 6S. Composition of clove oil

Table 7S. Composition of star anise oil

Table 8S. Composition of borneol crystals

Table 9S. Boiling point, vapor pressure, and lipophilicity of the main compounds in the essential oils [21] 
Tables

Table 1S. Composition of galangal oil

\begin{tabular}{lcc}
\hline Compound $^{\mathrm{a}}$ & $\mathrm{RI}^{\mathrm{b}}$ & Peak Area(\%) $^{\mathrm{c}}$ \\
\hline 3-carene & 1062 & 1.3 \\
pentadecane & 1660 & 2.6 \\
ethyl cinnamate & 2199 & 30.6 \\
ethyl $p$-methoxycinnamate & 2417 & 62.5 \\
\hline Total identified & & 97.0 \\
unknown & 3.0 \\
\hline
\end{tabular}

${ }^{\mathrm{a}}$ Order of elution is on an InertCap-Wax column.

${ }^{\mathrm{b}} \mathrm{RI}$ is the retention index, calculated against C10-C26 n-alkanes on an InertCap-Wax column.

${ }^{\mathrm{C}}$ Peak area percentage is determined by calculating the peak area of the FID chromatogram.

Table 2S. Composition of patchouli oil

\begin{tabular}{lcc}
\hline Compound $^{\mathrm{a}}$ & $\mathrm{RI}^{\mathrm{b}}$ & ${\text { Peak Area }(\%)^{\mathrm{c}}}^{\circ}$ \\
\hline$\beta$-patchoulene & 1659 & 1.0 \\
seychellene & 1846 & 2.3 \\
$\alpha$-bulnesene & 1911 & 0.8 \\
anethol & 2006 & 1.0 \\
caryophyllene oxide & 2117 & 2.8 \\
cinnamyl aldehyde & 2151 & 0.9 \\
eugenol & 2223 & 1.0 \\
patchouli alcohol & 2230 & 66.2 \\
Total identified & & 76.2 \\
unknown & & 23.8 \\
\hline
\end{tabular}

${ }^{\mathrm{a}}$ Order of elution is on an InertCap-Wax column.

${ }^{\mathrm{b}} \mathrm{RI}$ is the retention index, calculated against C10-C26 n-alkanes on an InertCap-Wax column.

${ }^{\mathrm{C}}$ Peak area percentage is determined by calculating the peak area of the FID chromatogram. 
Table 3S. Composition of sandalwood oil

\begin{tabular}{lcc}
\hline Compound $^{\mathrm{a}}$ & $\mathrm{RI}^{\mathrm{b}}$ & ${\text { Peak Area }(\%)^{\mathrm{c}}}^{-}$ \\
\hline epi - $\beta$-santalene & 1832 & 1.1 \\
camphenenol & 2277 & 1.0 \\
$\alpha$-santalol & 2318 & 49.5 \\
(Z)-trans - $\alpha$-bergamotol & 2322 & 6.7 \\
cis - $\beta$-santalol & 2361 & 4.3 \\
trans - $\beta$-santalol & 2371 & 22.4 \\
Total identified & & 85.0 \\
unknown & & 15.0 \\
\hline
\end{tabular}

${ }^{\mathrm{a}}$ Order of elution is on an InertCap-Wax column.

${ }^{\mathrm{b}} \mathrm{RI}$ is the retention index, calculated against C10-C26 n-alkanes on an InertCap-Wax column.

${ }^{\mathrm{C}}$ Peak area percentage is determined by calculating the peak area of the FID chromatogram. 
Table 4S. Composition of spikenard oil

\begin{tabular}{lcc}
\hline Compound $^{\mathrm{a}}$ & $\mathrm{RI}^{\mathrm{b}}$ & Peak Area(\%) $^{\mathrm{c}}$ \\
\hline$\alpha$-copaene & 1665 & 0.9 \\
$\delta$-selinene & 1733 & 2.7 \\
aristolene & 1764 & 1.8 \\
calarene & 1792 & 15.7 \\
$\alpha$-gurjunene & 1821 & 3.0 \\
calaradiene & 1863 & 1.7 \\
anethol & 2006 & 0.7 \\
$\beta$-ionone & 2083 & 3.4 \\
$\beta$-ionon-5,6-epoxide & 2101 & 0.7 \\
ledol & 2141 & 0.8 \\
cinnamaldehyde & 2151 & 1.0 \\
(-)-globulol & 2166 & 2.3 \\
spathulenol & 2192 & 5.2 \\
patchouli alcohol & 2228 & 4.9 \\
Total identified & & 44.9 \\
unknown & 55.1 \\
\hline${ }^{\mathrm{a}}$ Order of elution is on an InertCap-Wax column. \\
${ }^{b}$ RI is the retention index, calculated against C10-C26 n-alkanes on an \\
InertCap-Wax column. \\
c Peak area percentage is determined by calculating the peak area of the \\
FID chromatogram. & \\
\hline
\end{tabular}


Table 5S. Composition of cinnamon oil

\begin{tabular}{lcc}
\hline Compound $^{\mathrm{a}}$ & $\mathrm{RI}^{\mathrm{b}}$ & ${\text { Peak Area }(\%)^{\mathrm{c}}}^{-}$ \\
\hline$\alpha$-copaene & 1668 & 2.0 \\
benzaldehyde & 1718 & 0.4 \\
$\alpha$-muurolene & 1920 & 0.5 \\
$\delta$-cadinene & 1949 & 0.9 \\
cinnamaldehyde & 2155 & 93.9 \\
$\alpha$-cadinol & 2251 & 0.5 \\
2-methoxycinnamaldehyde & 2385 & 1.9 \\
\hline Total identified & 100.0 \\
\hline${ }^{\mathrm{a}}$ Order of elution is on an InertCap-Wax column. \\
${ }^{\mathrm{b}} \mathrm{RI}$ is the retention index, calculated against C10-C26 n-alkanes on an \\
InertCap-Wax column. \\
${ }^{\mathrm{c}}$ Peak area percentage is determined by calculating the peak area of the \\
FID chromatogram. \\
\hline
\end{tabular}


Table 6S. Composition of clove oil

\begin{tabular}{lcc}
\hline Compound $^{\mathrm{a}}$ & $\mathrm{RI}^{\mathrm{b}}$ & Peak Area(\%) $^{\mathrm{c}}$ \\
\hline$\alpha$-copaene & 1668 & 0.2 \\
linalool & 1726 & 0.1 \\
trans -caryophyllene & 1803 & 12.6 \\
estragole & 1868 & 0.1 \\
humulene & 1874 & 1.5 \\
endo -borneol & 1899 & 0.2 \\
$\alpha$-farnesene & 1936 & 0.2 \\
$\delta$-cadinene & 1949 & 0.2 \\
methyl salicylate & 1972 & 0.2 \\
anethole & 2009 & 2.7 \\
caryophyllene oxide & 2119 & 0.2 \\
eugenol & 2222 & 75.0 \\
acetyleugenol & 2267 & 5.2 \\
allyl phenol & 2315 & 0.1 \\
Total identified & & 98.4 \\
unknown & & 1.6 \\
\hline
\end{tabular}

${ }^{\mathrm{a}}$ Order of elution is on an InertCap-Wax column.

${ }^{\mathrm{b}} \mathrm{RI}$ is the retention index, calculated against C10-C26 n-alkanes on an InertCap-Wax column.

${ }^{\mathrm{c}}$ Peak area percentage is determined by calculating the peak area of the FID chromatogram. 
Table 7S. Composition of star anise oil

\begin{tabular}{|c|c|c|}
\hline Compound $^{\mathrm{a}}$ & $\mathrm{RI}^{\mathrm{b}}$ & Peak Area(\%) ${ }^{\mathrm{C}}$ \\
\hline$\alpha$-pinene & 803 & 0.2 \\
\hline$d$-limonene & 1167 & 0.3 \\
\hline linalool & 1725 & 0.4 \\
\hline$\alpha$-bergamotene & 1777 & 0.2 \\
\hline caryophyllene & 1797 & 0.8 \\
\hline$\beta$-farnesene & 1866 & 0.2 \\
\hline estragole & 1872 & 1.9 \\
\hline$\alpha$-terpineol & 1890 & 0.2 \\
\hline endo -borneol & 1898 & 0.9 \\
\hline (Z )-anethole & 1950 & 0.2 \\
\hline (E )-anethole & 2013 & 91.1 \\
\hline anisaldehyde & 2144 & 1.6 \\
\hline eugenol & 2216 & 0.8 \\
\hline Total identified & & 98.8 \\
\hline unknown & & 1.2 \\
\hline
\end{tabular}

${ }^{\mathrm{a}}$ Order of elution is on an InertCap-Wax column.

${ }^{\mathrm{b}} \mathrm{RI}$ is the retention index, calculated against C10-C26 n-alkanes on an InertCap-Wax column.

${ }^{\mathrm{C}}$ Peak area percentage is determined by calculating the peak area of the FID chromatogram.

Table 8S. Composition of borneol crystals

\begin{tabular}{lcc}
\hline Compound $^{\mathrm{a}}$ & $\mathrm{RI}^{\mathrm{b}}$ & ${\text { Peak Area }(\%)^{\mathrm{c}}}^{-1867}$ \\
\hline isoborneol & 1867 & 21.6 \\
borneol & 1899 & 70.0 \\
\hline Total identified & & 91.7 \\
unknown & & 8.3 \\
\hline
\end{tabular}

${ }^{\text {a }}$ Order of elution is on an InertCap-Wax column.

${ }^{b} \mathrm{RI}$ is the retention index, calculated against C10-C26 n-alkanes on an InertCap-Wax column.

${ }^{\mathrm{c}}$ Peak area percentage is determined by calculating the peak area of the FID chromatogram. 
Table 9S. Boiling point, vapor pressure, and lipophilicity of the main compounds in the essential oils. ${ }^{\text {[21] }}$

\begin{tabular}{llrrr}
\hline \multicolumn{1}{c}{ Main compound } & $\begin{array}{c}\text { Boiling Point } \\
\left.\text { (at 760 mmHg, }{ }^{\circ} \mathrm{C}\right)\end{array}$ & $\begin{array}{c}\text { Vapor Pressure } \\
\left(\text { at } 25{ }^{\circ} \mathrm{C}, \mathrm{mmHg}\right)\end{array}$ & $\begin{array}{c}\text { Lipophilicity } \\
(\operatorname{logP}(\mathrm{o} / \mathrm{w}))\end{array}$ \\
\hline galangal & ethyl $p$-methoxycinnamate & $325-326$ & 0.000235 & 2.650 \\
patchouli & patchouli alcohol & $287-288$ & 0.000278 & 4.484 \\
sandalwood & $\alpha$-santalol & 302 & 0.000002 & 4.647 \\
spikenard & calarene & 260 & 0.020000 & 6.252 \\
borneol crystals & borneol & 212 & 0.040000 & 3.240 \\
cinnamon & cinnamaldehyde & $249-252$ & 0.026500 & 1.900 \\
clove & eugenol & $252-253$ & 0.010000 & 2.270 \\
star anise & anethole & $234-237$ & 0.069000 & 3.390 \\
\hline
\end{tabular}

Figure 1S

(a)<smiles>CCOC(=O)/C=C/c1ccc(OC)cc1</smiles>

ethyl $p$-methoxycinnamate

(b)

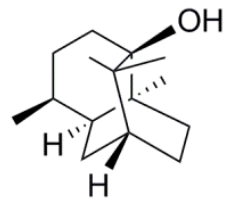

patchouli alcohol

(c)<smiles>C/C(=C\CC[C@]1(C)CC2C3CC1C2(C)C3)CO</smiles>
alpha-santalol

(d)<smiles>C[C@H]1CCC=C2CC[C@H]3[C@H](C3(C)C)[C@]21C</smiles>

calarene ethyl cinnamate<smiles>CCOC(=O)/C=C/c1ccccc1</smiles><smiles>C=C1CCCC2(C)O[C@H]2CC[C@H]2C(C)C[C@H]12</smiles>

caryophyllene oxide (e)<smiles>O=C/C=C/c1ccccc1</smiles>

cinnamaldehyde<smiles>CC1=CCC2C1CC1C2CC[C@H]1C(C)C</smiles>

alpha-copaene

(f)<smiles>C=CCc1ccc(O)c(OC)c1</smiles>

eugenol<smiles>C=C1CC/C=C(/C)CC[C@@H]2[C@@H]1CC2(C)C</smiles>

trans-caryophyllene

(g)<smiles>C/C=C/c1ccc(OC)cc1</smiles><smiles>C=CCc1ccc(OC)cc1</smiles>

(E)-anethole

estragole

(h)<smiles>CC1(C)[C@@H]2CC[C@H]1OC2</smiles>

borneol

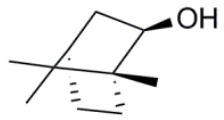

isoborneol 